\title{
Faktor Yang Mempengaruhi Kecemasan Pada Tenaga Kesehatan Dalam Upaya Pencegahan Covid-19 \\ Nur Aini Lubis
}

\section{Email: $\underline{\text { nrnlubis@gmail.com }}$}

\section{Latar Belakang:}

Pada awal 2020, dunia dikejutkan dengan mewabahnya pneumonia baru yang bermula dari Wuhan, Provinsi Hubei yang kemudian menyebar dengan cepat ke lebih dari 190 negara dan teritori. Wabah ini diberi nama coronavirus disease 2019 (COVID-19) yang disebabkan oleh Severe Acute Respiratory Syndrome Coronavirus-2 (SARS-CoV-2). Penyebaran penyakit ini telah memberikan dampak luas secara sosial dan ekonomi.

Banyak para petugas kesehatan dari tingkatan atas hingga bawah bekerjasama dalam membantu para korban covid. Tapi tidak sedikit para tenaga kesehatan yang justru terkena penyakit mematikan ini.kurangnya alat pelindung diri dan pasien yang terus berdatangan, membuat para tenaga kesehatan harus siap hidup dan mati.

Para tenaga kesehatan harus selalu siap, kapanpun dibutuhkan. Karena itu, banyak dari perawat yang harus selalu di rumah sakit. Para perawat harus meninggalkan keluarga, karena resiko membawa penyakit corona kepada keluarga dirumah.

Banyak faktor yang menyebabkan kecemasan pada para perawat. Dari harus siap terkena corona. Istirahat yang tidak cukup, jauh dari keluarga dan yang lainnya.

\section{PENDAHULUAN}

Dengan maraknya berita tentang CORONA atau sering disebut Covid-19, membuat banyak kalangan khawatir. Termasuk perawat sebagai salah satu tenaga kesehatan.

Sering sekali para perawat dilanda depresi, kecemasan berlebihan, dan stres. Karena mereka harus selalu berada di garda depan untuk melawan covid-19. Mereka juga harus selalu memberikan peringatan kepada warga-warga yang "nakal", yang tidak mau mengikuti prosedur kesehatan. Harus siap mendengar hujatan kejahatan dari oknum yang tidak mau diatur dalam mengikuti prosedur kesehatan.

World Health Organization (WHO) melaporkan ada lebih dari 22.000 petugas medis yang tersebar di 52 negara dan wilayah dinyatakan telah terinfeksi virus corona (Covid-19). Laporan itu dirilis pada Sabtu (11/4/20) berdasarkan data per Rabu (8/4/20). Dalam laporan itu menyebutkan, setidaknya ada 22.073 kasus Covid-19 yang merupakan petugas kesehatan. Para petugas kesehatan tersebut diketahui terinfeksi ketika merawat dan menangani pasien 
Covid-19. Meski begitu, WHO mengungkapkan, jumlah tersebut sebenarnya jauh lebih besar mengingat tidak ada laporan sistematis mengenai infeksi di antara petugas kesehatan.

\section{BAHAN DAN METODE}

Pengumpulan data dengan menggunakan kuesioner/angket sebagai alat pengumpulan data berdasarkan panduan nasional keselamatan pasien (Patient Safety) yang disusun oleh Komite Akreditasi Rumah Sakit Departemen Kesehatan.

Pengumpulan data juga dilakukan dengan bantuan jurnal-jurnal kesehatan dan hasil penelitian para pakar kesehatan.

Metode penelitian dilakukan dengan cara, mengumpulkan bahan-bahan berupa jurnaljurnal kesehatan tentang kesehatan, data-data dari pakar kesehatan dan organisasi kesehatan dunia atau WHO.

Setelah semua bahan dan data juga informasi didapatkan, semua data di pilah dan disusun agar menjadi sebuah hasil penelitan yang ringkas dan gampang untuk dibaca dan dipahami. Semua data dan informasi dirangkum sesuai jenisnya.

\section{HASIL DAN PEMBAHASAN}

Dari data yang didapat dan disusun, kita tahu bahwa semua orang dapat terkena penyakit, termasuk para tenaga kesehatan.

Dimasa pandemi COVID-19 ini, semua tenaga kesehatan harus turut serta dalam mengobati dan merawat para pasien COVID-19.

sosiasi organisasi profesi tenaga kesehatan di Indonesia mencatat setidaknya 6.680 petugas medis terinfeksi Covid-19 selama pandemi sejak kasus pertama diumumkan awal Maret 2020.

Jumlah kematian petugas medis itu terdiri dari 2.979 perawat, 2.291 bidan, 803 apoteker, 115 orang dokter gigi, dan 492 petugas di laboratorium medik yang memeriksa sampel spesimen.

Dari jumlah tenaga medis yang terinfeksi, sebanyak 234 petugas atau tenaga medis diantaranya, meninggal akibat terinfeksi virus SARS-CoV-2 ini. Terdiri dari 117 dokter, enam apoteker, 22 bidan, 85 perawat, dan empat petugas laboratorium medik.

Data tersebut dihimpun oleh Ikatan Dokter Indonesia (IDI), Persatuan Perawat Nasional Indonesia (PPNI), Ikatan Bidan Indonesia (IBI), Persatuan Dokter Gigi Indonesia (PDGI), Ikatan Apoteker Indonesia (IAI), dan Persatuan Ahli Teknologi Laboratorium Medik Indonesia (Patelki). 
Ketua Umum Pengurus Besar Ikatan Dokter Indonesia (IDI) Daeng Faqih mengatakan penularan di antara tenaga kesehatan tergolong tinggi karena bersentuhan dengan pasien Covid-19.

Menurut Daeng, asosiasi organisasi kesehatan telah berdiskusi dengan pemerintah untuk memfasilitasi pemeriksaan rutin terhadap tenaga medis.

"Kami berharap dengan terperiksanya secara rutin, itu akan menekan risiko yang serendah-rendahnya risiko penularan," kata Faqiah melalui konferensi pers virtual di Jakarta, Selasa.

Pemeriksaan sudah mulai berjalan di Jabodetabek, namun IDI berharap hal serupa bisa segera dilaksanakan di daerah dengan kasus Covid-19 yang cukup tinggi seperti Jawa Barat, Jawa Tengah, Jawa Timur, dan Bali.

Pemerintah juga diminta terus menambah kapasitas pelayanan di fasilitas kesehatan agar tenaga medis tidak kelelahan.

Selain itu, IDI juga mengimbau agar masyarakat mematuhi protokol kesehatan untuk mengurangi risiko penularan.

Karena risikonya yang sangat tinggi, para tenaga medis perlu menerapkan prosedur dan protokol tertentu untuk mencegah penularan virus. Prosedur dan protokol untuk mencegah infeksi termasuk kontrol lingkungan, kontrol administratif, praktik kerja yang lebih aman dan alat pelindung diri. Melansir dari beberapa sumber, berikut prosedur dan protokol yang harus ditaati petugas medis agar tidak tertular virus corona:

\section{Melatih, Mengedukasi, dan Memantau Tenaga Medis}

Sebelum mengedukasi pengunjung, tentunya para tenaga medis harus memahami instruksi pencegahan penyakit terlebih dahulu. Setiap tenaga medis harus mendapatkan edukasi dan pelatihan tentang pemakaian Alat Pelindung Diri (APD) sebelum merawat pengidap virus corona. Pastikan mereka memahami cara penanggulangan terhadap pakaian, kulit, dan lingkungan yang terkontaminasi.

Melansir dari Centers for Disease Control and Prevention, tenaga medis yang dicurigai tertular coronavirus harus dibebaskan dari pekerjaan selama 14 hari dan kondisinya harus selalu dipantau. Tenaga medis yang mengalami gejala penyakit pernapasan juga harus segera melapor untuk diperiksa lebih lanjut.

\section{Mematuhi Protokol Pencegahan Penyakit}


Selain meminimalisir peluang paparan, tenaga medis wajib mematuhi protokol pencegahan penyakit berikut:

\section{- Menjaga Kebersihan Tangan}

Para tenaga medis harus menjaga kebersihan tangan sebelum dan setelah melakukan kontak dengan pengidap, kontak dengan bahan yang berpotensi menular, sebelum memakai dan setelah melepas alat pelindung pribadi (baju, masker, sarung tangan dan lain-lain). Cuci tangan dengan sabun dan air setidaknya selama 20 detik atau menggunakan pembersih tangan yang mengandung 70 persen alkohol.

\section{- Mengenakan Alat Pelindung Diri (APD)}

Tenaga medis wajib mengenakan APD sekali pakai yang meliputi, baju pelindung khusus, sarung tangan, masker, dan pelindung mata. Alat pelindung ini hanya bisa sekali pakai, sehingga tenaga medis harus melepas dan membuangnya setelah keluar dari ruang perawatan atau bersinggungan dengan pasien.

\section{Meminimalisir Kemungkinan Paparan}

Dikutip dari Centers for Disease Control and Prevention, langkah-langkah harus diterapkan untuk meminimalkan peluang paparan dibagi menjadi tiga bagian, yakni sebelum kedatangan pengunjung, pada saat kedatangan dan selama menangani pengunjung, yaitu:

\section{- Sebelum Kedatangan}

Instruksikan kepada seluruh masyarakat untuk mengenakan masker wajah yang sudah dianjurkan. Masker ini wajib digunakan, terutama untuk seseorang yang mengalami gejala infeksi pernapasan, seperti batuk, pilek, demam.

\section{- Saat Kedatangan}

Beri tahu pengunjung yang mengalami gejala dan pastikan mereka untuk mematuhi etika batuk, mengenakan masker dan menjaga kebersihan dengan mencuci tangan selama kunjungan. Lebih baik jika instruksi ini dibuat dalam bentuk poster untuk ditempel di pintu masuk dan di tempat-tempat strategis agar pengunjung mengetahui dan menaati instruksi tersebut.

Selain itu, pastikan seseorang yang diduga terjangkit virus duduk sejauh mungkin dari orang lain yang masih sehat. Bila memungkinkan, sediakan area terpisah untuk menempatkan pengunjung selama mereka menunggu giliran pemeriksaan. 


\section{- Selama Penanganan}

Lakukan prosedur triase untuk mendeteksi pengunjung yang berisiko megalami infeksi coronavirus selama atau sebelum triase atau pada saat pengunjung check-in. Triase adalah proses seleksi pasien yang diprioritaskan untuk mendapat penanganan terlebih dahulu. Pastikan semua pengunjung ditanya tentang adanya gejala infeksi pernapasan dan riwayat perjalanan ke daerah yang mengalami penularan coronavirus atau kontak dengan seseorang yang mungkin mengidap virus corona.

\section{Mengatur Pergerakan di Dalam Rumah Sakit}

Seluruh tenaga pekerja rumah sakit harus bekerja sama untuk memantau, mengelola, dan mengedukasi pengunjung untuk mencegah penularan virus korona. Pastikan pengunjung tidak melakukan kontak dengan yang lainnya, terutama pada orang yang mengalami gejalagejala mencurigakan sebelum menjalani pemeriksaan.

\section{Pengendalian Infeksi di Lingkungan Sekitar}

Untuk mengendalikan infeksi di lingkungan sekitar, lakukan prosedur pembersihan dan desinfeksi secara seksama dan konsisten. Bersihkan barang-barang yang sering disentuh dengan desinfektan sesuai standar.

\section{KESIMPULAN}

Untuk itu, semua orang harus selalu mengikuti protokol kesehatan dimanapun berada. Termasuk tenaga medis seperti perawat, harus selalu menjaga kebersihan diri.

Mengikuti anjuran dan saran dari pusat layanan kesehatan, Kementerian Kesehatan, WHO dan kesehatan lokal juga baik untuk Anda menghindari diri dari risiko terinfeksi virus corona. 


\section{DAFTAR PUSTAKA}

- Erni Murniasih,Andhika Rahmawati. 2007. HUBUNGAN DUKUNGAN KELUARGA DENGAN TINGKAT KECEMASAN AKIBAT HOSPITALISASI PADA ANAK USIA PRASEKOLAH DI BANGSAL L RSUP DR.SOERADJI TIRTO NEGORO KLATEN TAHUN 2007. Jurnal Kesehatan Suya Medika Yogyakarta.

- Fadli, F., Safruddin, S,. Ahmad, A.S., Sumbara, S,. \& Baharuddin, R. 2020. Faktor yang Mempengaruhi Kecemasan pada Tenaga Kesehatan Dalam Upaya Pencegahan Covid-19. Jurnal Pendidikan Keperawatan. Volume.6,No.1

- $\quad$ Rina Tri Handayani, Suminanto, Aquartuti Tri Damayanti, dkk. 2020. KONDISI DAN STRATEGI PENANGANAN KECEMASAN PADA TENAGA KESEHATAN SAAT PANDEMI COVID-19. Jurnal Ilmu Keperawatan Jiwa Volume 3 No 3, Hal 365 - 374, Agustus 2020

- Rina Tri Handayani, Saras Kuntari,dkk. 2020. FAKTOR PENYEBAB STRES PADA TENAGA KESEHATAN DAN MASYARAKAT SAAT PANDEMI COVID-19. Jurnal Keperawatan Jiwa. Volume 8 No 3, Agustus 2020, Hal $353-360$

- $\quad$ Pedoman Dukungan Kesehatan Jiwa Dan Psikososial Pada Pandemi COVID-19

- $\quad$ Rizka Ausrianti, Rifka Putri Andayani, dkk. 2020. EDUKASI PENCEGAHAN PENULARAN COVID 19 SERTA DUKUNGAN KESEHATAN JIWA DAN PSIKOSOSIAL PADA PENGEMUDI OJEK ONLINE. Jurnal Peduli Masyarakat, Volume 2 No 2 Hal 59 - 64, Juni 2020

- $\quad$ Adityo Susilo., C. Martin Rumende., dkk. 2020. Coronavirus Disease 2019: Tinjauan Literatur Terkini. Jurnal Penyakit Dalam Indonesia. Vol.7,No.1

- Yuliana. 2020. Corona Virus Diseases (Covid-19); Sebuah Tinjauan Literatur. Wellness And Healty Magazine. Vol.2,No.1

- $\quad$ Tania Amelia. Healthcare Workers Security. Vol.1,No.2

- $\quad$ Lilin Rosyanti, Indriono Hadi. 2020. Dampak Psikologis Dalam Memberikan Perawatan Dan Layanan Kesehatan Pasien COVID-19 Pada Tenaga Profesional Kesehatan. Jurnal Poltekkes. Vol.12,No.1

- Simamora, R. H. (2020). Pelatihan Komunikasi Efektif untuk Meningkatkan Efikasi diri Perawat dalam Pelaksanaan Identifikasi Pasien. JURNAL ILMIAH KESEHATAN MASYARAKAT: Media Komunikasi Komunitas Kesehatan Masyarakat, 12(1), 49-54. 
